\title{
PENGARUH KUALITAS PRODUK DAN HARGA TERHADAP KEPUTUSAN PEMBELIAN ROKOK SURYA (Studi Kasus pada Konsumen Rokok Surya di UNISLA)
}

\author{
Abid Muhtarom ${ }^{1}$ \\ Fakultas Ekonomi, Universitas Islam Lamongan \\ abid@unisla.ac.id \\ Muhammad Tommy Syahrizal ${ }^{2}$ \\ Fakultas Ekonomi, Universitas Islam Lamongan \\ clingur09@gmail.com
}

\begin{abstract}
ABSTRAK
Perusahaan yang memiliki image yang baik dimata konsumen umumnya akan lebih menarik calon konsumen karena mereka yakin bahwa perusahaan tersebut memiliki kualitas yang baik dan dapat dipercaya. Sebab dimata konsumen, perusahaan yang terpercaya adalah jaminan atas konsistensi kinerja suatu produk dan penyediaan manfaat apapun yang dicari konsumen ketika membeli produk dari perusahaan tersebut. Jenis penelitian ini menggunakan jenis penelitian diskriptif kuantitatif dengan menggunakan metode kuesioner untuk pengumpulan datanya, Teknik pengambilan sampel menggunakan accidental sampling. Penelitian ini menggunakan alat analisis data antara lain Uji Validitas, Uji Reliabilitas, Uji Regresi Linier Berganda, Koefisien Determinasi, Uji $t$, Uji F. Dari hasil perhitungan analisis regresi linier berganda diperoleh nilai $K P G=6,178310+0,380369 K P+0,147771 H R G$ berdasarkan uji $t$ menunjukan nilai $t_{\text {tabel }}=1,989$, nilai $t_{\text {hitung }}$ untuk variabel kualitas produk $(K P)$ sebesar 7,712486 dan untuk variabel harga $(H R G)$ sebesar 2,708 $>t_{\text {tabel }}=1,989$. Sedangkan pada uji $F$ diperoleh nilai $F_{\text {hitung }}$ sebesar 50,55638 $>F_{\text {tabel }}=3,11$. Maka $H_{o}$ ditolak dan $H_{\alpha}$ diterima, sehingga dapat disimpulkan bahwa variabel kualitas produk dan harga secara parsial dan simultan berpengaruh signifikan terhadap keputusan pembelian.
\end{abstract}

Kata kunci : kualitas produk, harga dan keputusan pembelian

\section{PENDAHULUAN}

Persaingan yang begitu ketat menuntut perusahaan untuk mampu memaksimalkan kinerja perusahaan agar dapat bersaing dipasaran. Keberhasilan perusahaan dalam mempengaruhi konsumen dalam keputusan pembelian sangat di pengaruhi oleh upaya menumbuhkan kepercayaan konsumen. Kepercayaan konsumen terhadap perusahaan merupakan suatu aset yang tidak ternilai bagi perusahaan. Perusahaan yang memiliki image yang baik dimata konsumen umumnya akan lebih menarik calon konsumen karena mereka yakin bahwa perusahaan tersebut 
memiliki kualitas yang baik dan dapat dipercaya. Sebab dimata konsumen, perusahaan yang terpercaya adalah jaminan atas konsistensi kinerja suatu produk dan penyediaan manfaat apapun yang dicari konsumen ketika membeli produk dari perusahaan tersebut.

Berdasarkan penelitian terdahulu yang pernah dikukan oleh Widayati Dwi (2012) yang berjudul "Pengaruh Kualitas Produk Dan Harga Terhadap Keputusan Pembelian Produk Tupperware Di Yogyakarta”.

Berdasarkan penelitian terdahulu yang pernah dikukan oleh Arianto Nurmin (2016) yang berjudul "Pengaruh Kualitas Produk Dan Harga Terhadap Keputusan Pembelian Air Minum Dalam Kemasan (Amdk) Merek Aqua”.

Berdasarkan penelitian terdahulu yang pernah dikukan oleh Yazia Vivil (2014) yang berjudul "Pengaruh Kualitas Produk, Harga Dan Iklan Terhadap Keputusan Pembelian Handphone Blackberry (Studi Kasus Blackberry Center Veteran Padang)".

Berdasarkan penelitian terdahulu yang pernah dikukan oleh Tunis Janwar Anugrah, dkk (2016) yang berjudul "Pengaruh Kualitas Produk Dan Harga Terhadap Keputusan Pembelian Di The Secret Factory Outlet".
Berdasarkan penelitian terdahulu yang pernah dikukan oleh Anggara Robi, dkk (2012) yang berjudul "Pengaruh Kualitas Dan Harga Terhadap Keputusan Pembelian Laptop Acer Tipe Aspire 4752 Di Kelurahan Sepang Jaya Kecamatan Kedaton Bandar Lampung ". Berkaitan dengan hal tersebut diatas, maka perlu dilakukan suatu penelitian untuk mengetahui faktorfaktor yang mempengaruhi keputusan pembelian konsumen.

\section{METODE PENELITIAN}

Penelitian ini adalah penelitian deskriptif yang menggunakan pendekatan kuantitatif. Teknik analisa yang digunakan adalah teknik analisa deskriptif dan dengan menggunakan regresi berganda. Sedangkan sampel teknik yang digunakan adalah accidental sampling. Data yang di dapat akan di olah menggunakan alat statistika menurut Sugiyono (2015).

Data kuisioner yang digunakan dalam penelitian. Data ini bersumber dari jawaban responden Mahasiswa Fakultas Ekonomi Universitas Islam Lamongan Semester 1 tahun 2017 . menurut Sugiyono (2015).

Dalam penelitian ini menggunakan alat ananlisis Uji Validitas, Uji 
Reliabilitas, Uji Regresi Linier Berganda, Koefisien Determinasi, Uji t, Uji F menurut Sugiyono. (2015).

Persamaan data statistik yang diporoleh dari jurnal penelitian Anggara, Wibasuri, (2012), Arianto, Nurmin (2016), Habibah, Ummu (2015), Joshua, Padmalia (2016), Tunis, Martina (2016), Widayati, Dwi (2012) dapat memmberikan informasi dan kemajuan penelian dari permasalahan antara kualitas produk dan harga yang mempengaruhi keputusan pembelian dapat disimpulkan dalam rumus sebagai berikut :
$\mathrm{KPG}=\mathrm{a}+\mathrm{b}_{1} \mathrm{KP}_{1}+\mathrm{b}_{2} \mathrm{HRG}_{2}+\mathrm{e}$

Dimana dapat disimpulkan KPG = keputusan pembelian; $\mathrm{a}=$ konstanta; $\mathrm{KP} 1$ = kualitas produk $\mathrm{HRG}_{2}=$ harga, dan $\mathrm{e}=$ error

\section{HASIL DAN PEMBAHASAN}

Adapun teknik analisa data yang digunakan dalam variabel ini adalah :

1. Uji Validitas

2. Uji Reliabilitas

3. Uji Regresi Linier Berganda

4. Koefisien Determinasi

5. Uji t dan Uji F

\subsection{Uji Validitas}

Tabel 1. Uji Validitas

\begin{tabular}{clccc}
\hline No & \multicolumn{1}{c}{ Variabel/indicator } & $\mathbf{r}_{\text {hitung }}$ & $\mathbf{r}_{\text {tabel }}$ & Keterangan \\
\hline $\mathbf{1}$ & Produk (X1) & & & \\
& Indikator 1 (X1.1) & 0,854 & 0,212 & Valid \\
& Indikator 2 (X1.2) & 0,234 & 0,212 & Valid \\
\multirow{2}{*}{$\mathbf{2}$} & Indikator 3 (X1.3) & 0,215 & 0,212 & Valid \\
& Harga (X2) & & & \\
& Indikator 1 (X2.1) & 0,827 & 0,212 & Valid \\
& Indikator 2 (X2.2) & 0,438 & 0,212 & Valid \\
\multirow{3}{*}{$\mathbf{3}$} & Indikator 3 (X2.3) & 0,098 & 0,212 & Valid \\
& Keputusan pembelian (Y) & & & \\
& Indikator 1 (Y1.1) & 0,813 & 0,212 & Valid \\
& Indikator 2 (Y1.2) & 0,771 & 0,212 & Valid \\
& Indikator 3 (Y1.3) & 0,723 & 0,212 & Valid \\
\hline Sumber: Exel 2007, data quisoner & & &
\end{tabular}

Dengan $r_{\text {tabel }}$ pada $d f=n-2(86-2)$ dan probabilitas 0,05 diperoleh $r_{\text {tabel }}=0,212$ menunjukan bahwa semua indikator yang digunakan untuk mengukur variabel dalam penelitian ini mempunyai 
nilai $r_{\text {hitung }}>r_{\text {tabel }}$, artinya bahwa semua indikator dikatakan valid.

\subsection{Uji Reliabilitas}

Tabel 2. Uji Reliabilitas

\begin{tabular}{|c|r|}
\hline $\mathrm{R}_{\text {hitung }}$ & 0,48603 \\
\hline $\mathrm{R}_{\text {tabel }}$ & 0,2120 \\
\hline Reliabilitas & Reliabel \\
\hline
\end{tabular}

Sumber: Exel 2007, data quisoner

\subsection{Uji Regresi Linier Berganda}

Tabel 3. Koefisien Regresi

\begin{tabular}{cccrr}
\hline \hline Variable & Coefficient & Std. Error & t-Statistic & Prob. \\
\hline \hline C & 6.178310 & 0.672348 & 9.189159 & 0.0000 \\
KP & 0.380369 & 0.049319 & 7.712486 & 0.0000 \\
HRG & 0.147771 & 0.054566 & 2.708085 & 0.0082 \\
& & & & \\
\hline \hline
\end{tabular}

Sumber: Eviews 9, data quisoner

Berdasarkan tabel diatas hasil dari regresi berganda diatas maka dapat di bentuk suatu persamaan model regresi berganda sebagai berikut :

$$
\begin{aligned}
\mathrm{KPG}= & 6,178310+0,380369 \mathrm{KP}+ \\
& 0,147771 \mathrm{HRG}
\end{aligned}
$$

Dimana dapat disimpulkan KPG = keputusan pembelian; $\mathrm{a}=$ konstanta; $\mathrm{KP}_{1}$ = kualitas produk $\mathrm{HRG}_{2}=$ harga, dan $\mathrm{e}=$ error
Berdasarkan tabel diatas menunjukan bahwa semua nilai Cronbach's Alpha > 0,2120. Artinya semua variabel pada penelitian ini dinyatakan reliabel sehingga dinyatakan baik untuk penelitian.
Dari analisis di atas dapat disimpulkan bahwa, variabel yang memiliki pengaruh lebih dominan terhadap keputusan pembelian adalah variabel kualitas produk (KP) karena memiliki nilai sebesar 0,380369. Dengan demikian dapat dijelaskan bahwa hipotesis yang menyatakan variabel kualitas pelayanan paling dominan terhadap keputusan pembelian menurut Sugiyono (2015). 


\subsection{Koefisien Determinasi}

Tabel 4. Koefisien Determinasi

\begin{tabular}{lrlr}
\hline \hline R-squared & 0.549189 & Mean dependent var & 12.51163 \\
Adjusted R-squared & 0.538326 & S.D. dependent var & 0.979125 \\
S.E. of regression & 0.665282 & Akaike info criterion & 2.057050 \\
Sum squared resid & 36.73583 & Schwarz criterion & 2.142667 \\
Log likelihood & -85.45314 & Hannan-Quinn criter. & 2.091507 \\
F-statistic & 50.55638 & Durbin-Watson stat & 2.005820 \\
Prob(F-statistic) & 0.000000 & \\
\hline \hline
\end{tabular}

Sumber: Eviews 9, data quisoner

Dari analisis diatas diperoleh hasil perhitungan regresi yang dapat diketahui bahwa nilai koefisien determinasi $\left(R^{2}\right)$ yang diperoleh dari hasil $\mathrm{R}$ square sebesar 0,549189. Dari nilai $R^{2}$ tersebut dapat ditarik kesimpulan bahwa variabel kualitas produk dan harga secara bersama-sama telah mampu menjelaskan atau menerangkan keragaman dari variabel terikat yaitu keputusan pembelian. Pengaruh variabel kualitas produk dan harga terhadap keputusan pembelian memberikan kontribusi sebesar $54,9 \%$ sedangkan sisanya sebesar $45,1 \%$ dipengaruhi oleh faktor lain yang tidak diteliti. dan sisanya sebesar 49,4\%. Hal ini sesuai jurnal Anggara, Wibasuri, (2012), Arianto, Nurmin (2016), Habibah, Ummu (2015), Joshua, Padmalia (2016), Tunis, Martina (2016), Widayati, Dwi (2012) menolak jurnal sebelumnya bahwa pengaruh variabel kualitas produk (KP) dan harga (HRG) terhadap keputusan pembelian
(KPG) memberikan kontribusi sebesar $54,9 \%$ sedangkan sisanya sebesar $45,1 \%$ dipengaruhi oleh faktor lain yang tidak diteliti.

\section{$3.5 \quad$ Uji t}

Dari hasil analisis uji t (Tabel 3) diperoleh nilai $t_{\text {hitung }}$ kualitas produk $(7,712486)$ dan harga $(2,708085)$ sedangkan $t_{\text {tabel }}$ sebesar 1.989. Karena $t_{\text {hitung }}>t_{\text {tabel }}$ maka $H_{0}$ ditolak dan $H_{1}$ diterima artinya bahwa variabel bebas kualitas produk (KP) dan harga (HRG) secara parsial mempunyai pengaruh yang signifikan terhadap keputusan pembelian (KPG). Hal ini menerima jurnal Anggara, Wibasuri, (2012), Arianto, Nurmin (2016), Habibah, Ummu (2015), Joshua, Padmalia (2016), Tunis, Martina (2016), Widayati, Dwi (2012), bahwa variabel kualitas produk (KP) dan harga (HRG) secara parsial mempunyai pengaruh yang signifikan terhadap keputusan pembelian (KPG). 


\section{$3.6 \quad$ Uji F}

Dari analisis uji F (Tabel 4) diperoleh nilai $F_{\text {hitung }}$ sebesar 50,55638 sedangkan $F_{\text {tabel }}$ sebesar 3,11. Karena $F_{\text {hitung }}>F_{\text {tabel }}$ maka $H_{0}$ ditolak dan $H_{1}$ diterima artinya bahwa variabel bebas kualitas produk (KP) dan harga (HRG) secara simultan (bersama-sama) mempunyai pengaruh yang signifikan terhadap keputusan pembelian (KPG). Hal ini menerima jurnal Anggara, Wibasuri, (2012), Arianto, Nurmin (2016), Habibah, Ummu (2015), Joshua, Padmalia (2016), Tunis, Martina (2016), Widayati, Dwi (2012), bahwa variabel kualitas produk (KP) dan harga (HRG) secara simultan (bersama-sama) mempunyai pengaruh yang signifikan terhadap keputusan pembelian (KPG).

\section{PENUTUP}

Berdasarkan hasil penelitian seperti yang telah diuraikan pada bab sebelumnya dapat ditarik beberapa kesimpulan yaitu :

1. Dari kedua variabel yaitu kualitas produk dan harga secara parsial memiliki pengaruh signifikan terhadap keputusan pembelian rokok surya. Hal ini di buktikan dari nilai $\mathrm{t}_{\text {hitung }}$ kualitas produk $=7,712$ dan nilai sig. $\quad 0,000$ maka $t_{\text {hitung }}>t_{\text {tabel }}$
$(7,712>1,989)$ dan sig. $<0,05(0,000$

$<0,05)$, nilai $t_{\text {hitung }}$ harga $=2,708$ dan nilai sig. 0,008 maka $t_{\text {hitung }}>t_{\text {tabel }}$ $(2,708>1,989)$ sig. $<0,05(0,008<$ 0,05). Hal ini menerima jurnal Anggara, Wibasuri, (2012), Arianto, Nurmin (2016), Habibah, Ummu (2015), Joshua, Padmalia (2016), Tunis, Martina (2016), Widayati, Dwi (2012), bahwa variabel kualitas produk (KP) dan harga (HRG) secara parsial mempunyai pengaruh yang signifikan terhadap keputusan pembelian (KPG).

2. Dari hasil pengujian secara simultan diperoleh hasil analisis data nilai $\mathrm{F}_{\text {hitung }}=50,556$ dan nilai sig $=0,000$, maka $F_{\text {hitung }}>F_{\text {tabel }}(50,556>3,11)$ dan sig $<0,05(0,000<0,05)$. Dari kedua variabel yang terdiri dari kualitas produk dan harga berpengaruh signifikan terhadap keputusan pembelian rokok surya (studi kasus pada konsumen rokok surya di UNISLA). Hal ini menerima jurnal Anggara, Wibasuri, (2012), Arianto, Nurmin (2016), Habibah, Ummu (2015), Joshua, Padmalia (2016), Tunis, Martina (2016), Widayati, Dwi (2012), bahwa variabel kualitas produk (KP) dan harga (HRG) secara simultan (bersama-sama) mempunyai 
pengaruh yang signifikan terhadap keputusan pembelian (KPG).

Berdasarkan hasil analisis regresi $\mathrm{KPG}=$ $6,178310+0,380369 \mathrm{KP}+$ 0,147771HRG variabel yang memiliki pengaruh lebih dominan terhadap keputusan pembelian adalah variable kualitas produk (KP) karena memiliki nilai koefisien sebesar 0,380369. Hasil penelitian dari $t_{\text {hitung }}(\mathrm{KP})$ 7,712 lebih besar dibandingkan dengan (HRG). Hal ini menerima jurnal Habibah, Ummu (2015) bahwa hasil uji regresi berganda masing-masing variabel adalah KPG = $1,446+0,629(\mathrm{KP})+0,321(\mathrm{HRG})$. Dan hal ini menerima jurnal Anggara, Robi, dkk (2012) bahwa hasil uji regresi berganda masing-masing variabel adalah $\mathrm{KPG}=12,645+0,126(\mathrm{KP})+$ 0,151(HRG).

\section{DAFTAR PUSTAKA}

Anggara, Wibasuri, 2012. Pengaruh Kualitas Dan Harga Terhadap Keputusan Pembelian Laptop Acer Tipe Aspire 4752 Di Kelurahan Sepang Jaya Kecamatan Kedaton Bandar Lampung. Informatics and Business Institute Darmajaya, Vol 10, Hal 68-83.

Arianto, Nurmin 2016. Pengaruh Kualitas Produk Dan Harga Terhadap Keputusan Pembelian Air Minum Dalam Kemasan
(Amdk) Merek Aqua. Jurnal Ilmiah Prodi Manajemen Universitas Pamulang, Vol. 3, Hal 2-33.

Habibah, Ummu 2015. Pengaruh Kualitas Produk Dan Harga Terhadap Keputusan Pembelian Produk Kosmetik Wardah Di Kota Bangkalan Madura. Jurnal Ekonomi \& Bisnis, Vol 1, Hal 31 48

Joshua, Padmalia 2016. Pengaruh Kualitas Produk dan Harga Terhadap Keputusan Pembelian Konsumen. Jurnal Entrepreneur dan Entrepreneurship, Vol 5, Hal 27-32.

Sugiyono. 2015. Statistika Untuk Penelitian. Alfabeta, Bandung.

Tunis, Martina 2016. Pengaruh Kualitas Produk Dan Harga Terhadap Keputusan Pembelian Di The Secret Factory Outlet, Pariwisata, Vol. 3, Hal 60-73.

Widayati, Dwi 2012. Pengaruh Kualitas Produk Dan Harga Terhadap Keputusan Pembelian Produk Tupperware Di Yogyakarta, Jurnal Manajemen Vol. 2, Hal 65-74. 